\title{
Poems
}

\section{Stuart Cooke}

\section{Lurujarri}

a poem by foot

from Opera (2016)

(first)

it begins as

stumbling into that point of distant tinder

distance slides into darkness

we drag our winters

over a thick

scrub

of palpitating nerves

and moths

[star/light whispers calcite

and silicate

evening's fat as ant]

[thunder along a cable's salt]

it bulges into blister:

the structure of sweat

someone's geology trapped in the gunk beneath a nail 
then

we walked so far we missed the dance

rays squeezing out

like the neg ative

hairs from a pale leg

a dim day

$$
\begin{aligned}
& \text { across the flood plains } \\
& \text { the creation site / the broad banks } \\
& \text { beside a river's hidden crocodile }
\end{aligned}
$$

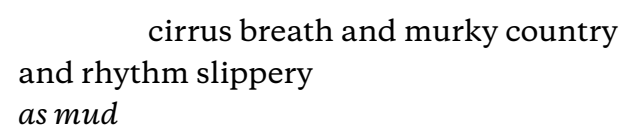

we kept following, the horde of us

the whole horde of us kept following

it was a dance $[\mathrm{a}$ fire (a cave)

by the time we arrived it was the story of it

we set up for rest

edges grumbling with storm

a swim's fresh glove

an evening's wet rattle

bugs whirling around in the beam $\}$

from my head 
(third)

later on, well after lunch

it's hard to sit down: floor's

$\wedge \wedge \wedge \wedge \wedge \wedge \wedge \wedge \wedge \wedge \wedge \wedge \wedge \wedge \wedge \wedge \wedge \wedge \wedge \wedge \wedge \wedge \wedge \wedge \wedge \wedge \wedge \wedge \wedge \wedge$

a hardened reef spotted with succulents

II

in the east the soupy storm

storm barrels towards the sea, squashing me

into the scrub, the storm's

a grey-navy mind \{mediating\{infinite \{

that group, I saw them between

bleeding land

blue brain

between the bleeding land and the blue brain

their spires heading north...

leaving without me

painting their lives into the shore:

cusp of tyre... without mine...

that moving

fibre through

dusk's crusted

grime

and the coral flutes OoOO00000000000

lpushing songs from the reef-

of day clearing and shining soprano

////////////////////////

refrains of tinge

and green

smear

I am the softest and the youngest time slowly melting older on a pock-marked clump
$\mathrm{O}$
$\mathrm{O}$
$\mathrm{O}$
$\mathrm{O}$
$\mathrm{O}$
$\mathrm{O}$ 


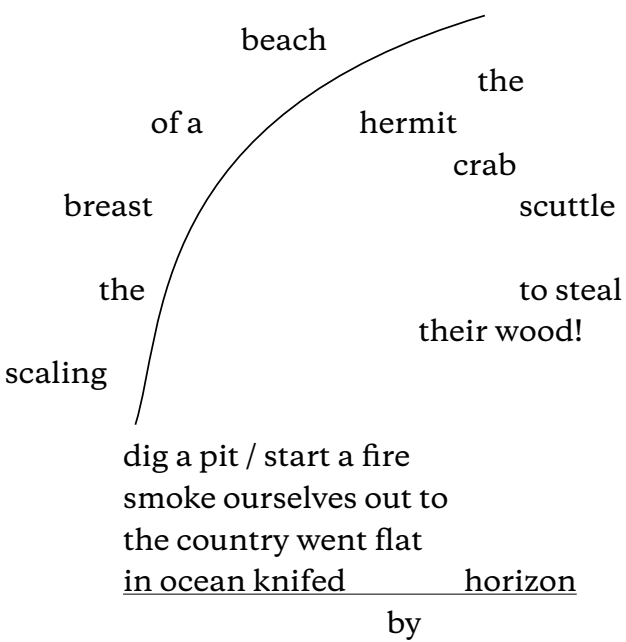

back south

dyubardyubbagun ignites the clouds sprung crystalline

*the odd drop ${ }^{\star}$
(pressure's seething plume)
${ }^{*}$ thock ${ }^{\star}$ that ${ }^{\star}$ thock

hermit crabs insist on the pit

$$
\text { tumble into it }
$$$$
\mathrm{U}
$$

the young

ones grab them up

\{chuck them in a basket crackling \{and clinking with the rest: smash

/the shells, catch bream octopus, dive/

with a knife/ stab a turtle

strip the curve from its back and cook up good tucker, crisp

and smokey... 
our sore toes hug powdery pindan

our tail's a road furry with scrub and palm / swim and warm

we chuckle your naked coals, snatch

and scratching at cliff, skeleton, relic scatter or dune-ish skeletal dunes scattered

angry cork spirits sleeping / we'll sleep here and call to noon

and be gone by noon 
this time

arrived in a cesspit: low beneath dunes

weeping smoke and stinking with still heat

sat and

waiting a while: flies drop on my face

like a rain of dried, crumbled shit

stick it out

sun stalked by cloud / catch the breeze

up top

swim and breeze and sear

foot cut on coral

my blood's billowing like worn silk

blood's like lace

kisses fish crap, clam puss

or a bottle contaminated by its own chemical

smoke's silent

flies munch on my wound

we walked to reach this, to move on

from this / our vines embering

and going dirt / jelly sweet

human giving, patter and mauve

red rock skewers fossil

and ocean 
(sixth)

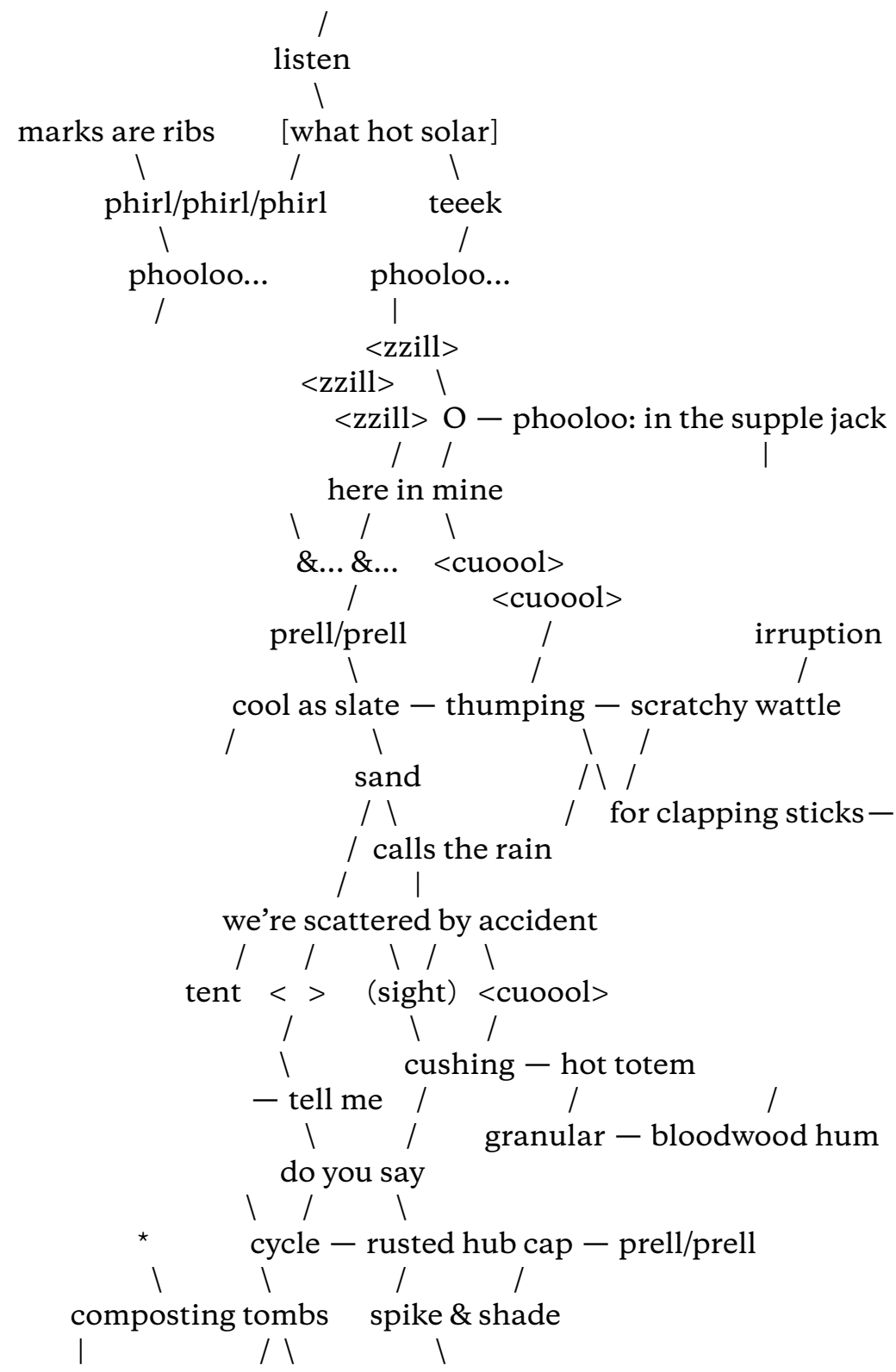


STUART COOKE : POEMS

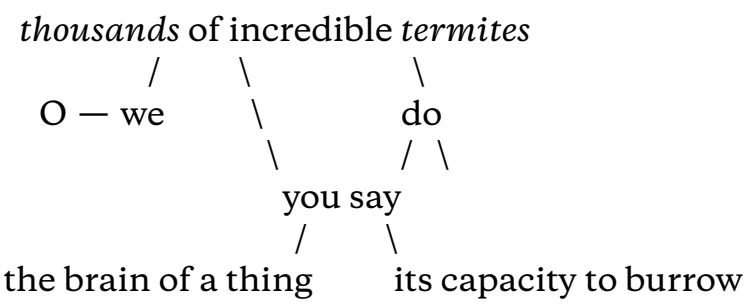


frigates flocking to fresh bilara

rain clamped down to force our fester

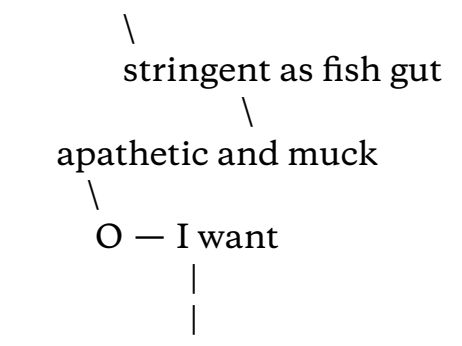

frigates flocking to fresh bilara

$\mathrm{O}$

I make bilara with my sweaty footprints

but knock a hole in me and I become billabul

I rip gills from dead bodies

1

$\mathrm{O}$

1

I want

।

|

movement

but all the roads speak RIVER

a spiky branch gouges out my scalp: this

country is sick of me

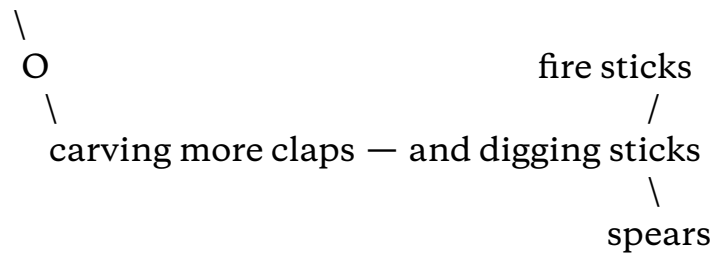


STUART COOKE : POEMS

\section{$\mathrm{I}-\mathrm{I}-\mathrm{I}-\mathrm{I}-\mathrm{I}-\mathrm{I}-\mathrm{I}-\mathrm{I}-\mathrm{I}-\mathrm{I}-\mathrm{I}-\mathrm{I}$ cumulonimbus punch} the cliffs|

$\mid \operatorname{shhh} .$.

|shhhhh...

|hurl and sodden!

|shhhhhhh...

lhurl and

|soak and

lsoak

and the dunes shift their bulk south

our images swim north

spurting and dugong against road 
(eighth)

feet on a clean floor too soon The rain's persistence drove us back the line shredded by torrents barely tied to its last thought and now, fading country and now, juicy fillets and capsules of linen can we sing back a coast that ends in the sign of the first and the always line of the wind's unrelenting hakea of survival as an obdurate succulent

: mine is a skin without flesh my footsteps grow anxious I walk the globe without a sign of I 
(ninth)

I washed the dirt from my chest

pindan rust in moon dish

(•)

they called I

wandered to the sunset

$\mathrm{O}$

the sun dragged the o cean down with it

I walked across cimmerian sea beds

[feet] stomach damp, soaring way

I walked an instant

$\mathrm{X}$

$\mathrm{O}$

but their stars pulled at me their floating stars L

E

D

or: some kind of coda

we populated the country together we left together

we together are a lantern huddled before the throat I

we broke up a chunk of elegy and ate it in rolls and photographs

we are an eddy and we 
I have the eyes and the nose of the houses cars drive over me / push me deeper into the earth - a slip of bay slithers over the mangroves

- a sky riddled with roots and with hope

- a tracing of the many through the one
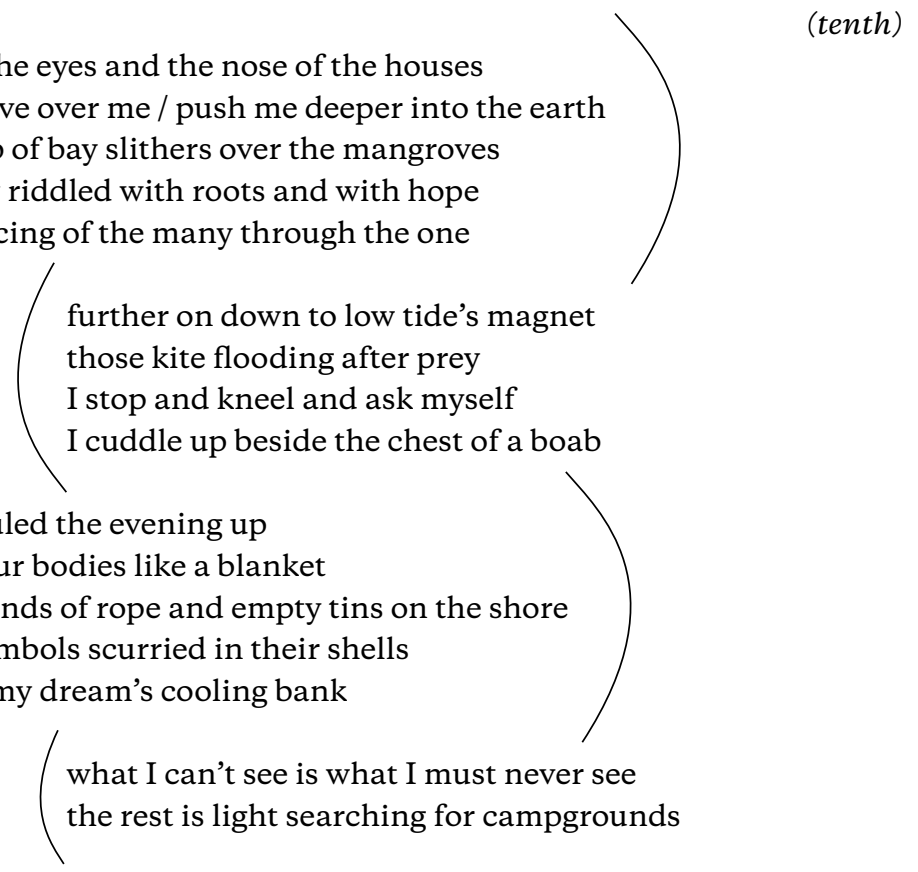

you hauled the evening up over your bodies like a blanket left strands of rope and empty tins on the shore your symbols scurried in their shells across my dream's cooling bank

$$
\begin{aligned}
& \text { what I can't see is what I must never see } \\
& \text { the rest is light searching for campgrounds }
\end{aligned}
$$

a sail on the trail's pink dust

$$
\begin{aligned}
& \text { ) dancing } \\
& \text { ) dancing }
\end{aligned}
$$

the poems are waterholes or they are the thinnest creeks skin-thin, moist bead and nervous wire

but you are coal and its capacity for ember you are you or $\mathrm{O}$

the angle invented by a king brown lush and poison between granules

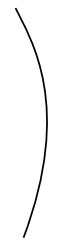

$$
\left(\begin{array}{ll}
\cdot & \text { I awoke inside the boab } \\
\cdot & \text { it was full of sea-weedy fumes } \\
\cdot & \text { we packed up and moved on without me }
\end{array}\right.
$$


Extracts from George Dyungayan's Bulu Line: A West Kimberley Song Cycle, featuring George Dyungayan, Paddy Roe, Ray Keogh \& Stuart Cooke

\section{Verse 11}

milydyidawurruy

dyalbirrimbirrai

yarany yarany yinydyarrgana

milydyidawurruy

[milydyidawurru: 'rainstorm from the south']

dyalbirrimbirrai

['storm building up']

yarany yarany

[yarany: a waterhole in Garadyarri country,

northwest of La Grange]

yiny-dyarrga-na

['it stood over, it waited, it hung over']

Roe: dyalbirrimbirrai cloud all heap up yarany yarany yinydyarrgana it's raining in Narany

Keogh: $\quad$ According to Roe, Verse 11 describes how it rained at Narany, a waterhole near Dampier Downs Station. Dyungayan could tell it was raining, says Roe, becausehe could see the clouds building up to the south of the Roebuck Plains.

Roe: $\quad$ rain from this way ${ }^{1}$ milydyidawurru we call im rain anytime cloud come we call im milydyidawurru [rhythmicises words] milydyidawurruy 
dyalbirrimbirrai

ah he making up you know dyalbirrimbirri rain they bin see im from long way too

Keogh: Dyungayan stated that the verse refers only to the clouds, and not to any rainfall. However, on another occasion he seemed to contradict this interpretation.

Dyungayan: wila I look im all the rain ${ }^{2}$

Keogh: $\quad$ Verse $\mathbf{1 1}$ accompanies a dance, but neither Roe nor Dyungayan could remember the lirrga.

Cooke: it's a rainstorm from the south

all that rain

the storm's building up

clouds heaping up

hanging over Narany

raining in that country

rainstorm in the south

over the waterhole

in Garadyarri country

all that rain

storm growing

standing over Narany

waiting there

in the south

the storm's building

the clouds are growing

the storm's hanging

over Narany

it's raining on the waterhole

in the south

the storm's building up... 


\section{Verse 12}

bandirr yarrabanydyina

burarriyiyanydyina

dyalal yindinayana

bandirr yarra-ba-ny-dyina

[body designs] ['we see him']

burarr-i yi-na-ny-dyina

[dim] ['he's there']

dyalal yin-di-na-yana

[ø] ['he did']

Roe: bandirr yarrabanydyina we seen bandirr burarri can't see proper long way dyalal yindinayana he come out from dark

Keogh: According to Roe, a group of rai were painted up with body designs in preparation for corroboree. They used the white ochre from Verse 3 (galydyi). In his dream, Dyungayan saw them emerge from the dark, but they didn't come close so he couldn't see them clearly.

Verse 12 is the lirrga for Verse 13.

Roe: that one something bin come out bandirr bandirr bilongu corroboree you know bandirr dyalal yindina he come out from dark you know other side

he come out in open burarr yinanydyina means oh

burarr he stop long way can't see im proper you know burarr

he just come out and he can only just see im that bandirr

rai bin come out dancing in dream 
Cooke: something's emerging

something's coming out

from the other side into the open

but it's dark their faint white ochre lines

they're painted up

slowly emerging

dancing in the dim light can't see them properly dancing far away

can barely make them out

dancing white ochre

the dancing rai in the open

far away

the faint forms of a dream

the rai emerging ready for corroboree... 


\section{Verse 13}

dadyiwurrurruy

dyunbarambara

ganal yimbanydyinayana

dadyi-wurrurruy

[ø] ['large group of people’]

dyunbarambara

[dyunbara: dust cloud]

ganal yim-ba-ny-dyina-yana

[ø] [yimbanydyina: 'he sees him']

Roe: ganal yimbanydyinayana he come to nothing ${ }^{3}$

Keogh \& Roe: R - he come out now this fella

[rhythmicises words] dadyiwurrurruy

dyunbarambara

dyunbarambara means he bring dust you know

with his foot

he come to nothing

but he bin dust coming out dyunbarambara ganal yimbanydyina and he come to nothing when he's high up wind blow im away you know

you can't see any more dust

$\mathrm{K}$ - so what's that dadyiwurrurruy wurrurruy?

$\mathrm{R}$ - dadyiwurrurruy that's them people coming out the ${ }^{4}$

for dance they're dancing dadyiwurrurruy wurrurru yijan like big mob coming dadyi nothing to make that corroboree

Keogh: According to Roe, in this verse the rai from Verse 12 come out in full view and begin to 
dance. As they stamp the ground, clouds of dust rise up from their feet. The wind blows the dust away, however, so it comes to nothing.

Butcher Joe \& Dyungayan:

$\mathrm{D}$ - this one nurlu I bin get im long time ago when I was a young young fella

B - that old man name Bulu that from Wanydyal an he sing for sing an dance that one now dadyiwurrurru he make dust one time we come from Beagle Bay run to thatplace there 5 somebody dancing there we look he dancing marlu ginya murda he gone 6 $\mathrm{D}$ - well that one now

Keogh: $\quad$ According to Butcher Joe, however, it isn't the rai who appear, but Bulu himself: Bulu is dancing.

Butcher Joe links the verse to a historical event in which a group of people were travelling from Beagle Bay. They saw a lot of dust caused by somebody dancing. The dancer was Bulu, but when they looked closer he had gone.

Dyungayan confirmed Butcher Joe's explanation. 
Cooke: that big mob coming

they're dancing

they see dancing

that big dust cloud

they're making corroboree

that big dust cloud

somebody's dancing

they're dancing

they see him dancing

that mob travelling

their big corroboree

that dust cloud

the wind blows

blows

carries the dust away

they see him dancing

that big travelling mob

they're dancing

he's kicking up dust

clouds of dust

the wind blows

he's gone

the dust's blown away

\section{that big mob}

they're dancing

they see him dancing...

\section{Notes}

Keogh: the rain came from the south.

Keogh: 'wila' is water/rain

Keogh: 'he' refers to the dust.

Keogh: 'them people' are rai.

Keogh: 'that place there' might be the Roebuck Plains.

Butcher Joe: "'marlu ginya murda not him nothing he's gone". 